\title{
Can professionals actually enable occupational justice?
}

\author{
Elizabeth Townsend ${ }^{\mathrm{a}}$, Rebecca Marval ${ }^{\mathrm{b}}$
}

aPhD, OT(C), Reg. PEI, FCAOT, Professor Emerita, School of Occupational Therapy Dalhousie University, Halifax, Nova Scotia, and Adjunct Professor, University of Prince Edward Island, Charlottetown, Prince Edward Island ${ }^{\mathrm{b} B S c}(\mathrm{OT}), \mathrm{OT}(\mathrm{C})$, Reg. NS, Occupational Therapist, Mobile Outreach Street Health (MOSH) Program, Halifax, Nova Scotia, and Tutor in the entry-level MSc (Occupational Therapy) program at Dalhousie University, Halifax, Nova Scotia, Canada

\begin{abstract}
Where everyday injustice - occupational injustice - persists, health and social professionals have an ethical, moral and professional obligation to reduce injustice with and for destitute as well as privileged members of society. But can professionals actually enable occupational justice? This reflective paper takes readers on a journey toward optimistically responding maybe. The analytic approach is summarized in preparation for tracing when and how the awakening to occupational injustice began. The journey continues by highlighting resources - namely a YouTube film: Reaching Out: Today's Activist Occupational Therapy and selected English language references from occupational science and occupational therapy that display an emerging knowledge bank for six population-based occupational justice practices which could be enriched with resources in other languages and fields. The journey ends with reflections on the complex professional power relations that need careful attention by professionals who intend to enable occupational justice.
\end{abstract}

Keywords: Critical Reflexivity, Knowledge Generation, Occupational Science, Professional Practice.

\section{Profissionais podem realmente promover justiça ocupacional?}

Resumo: Onde a injustiça cotidiana - injustiça ocupacional - persiste, profissionais das áreas social e de saúde têm obrigação profissional, moral e ética de reduzir tal injustiça para com os membros da sociedade, tanto para os necessitados como para os privilegiados. Mas os profissionais são realmente capazes de promover justiça ocupacional? Este estudo reflexivo leva seus leitores a uma viagem para responder, de forma otimista: talvez. A abordagem analítica resume-se na preparação para o delineamento de como e quando o despertar para a injustiça ocupacional começou. A viagem continua, destacando os recursos, a saber, um filme no YouTube: Estendendo a mão: a atual terapia ocupacional ativista e referências em língua inglesa selecionadas da ciência ocupacional e terapia ocupacional que apresentam um emergente banco de dados para seis práticas de justiça ocupacional com base em alguns grupos populacionais, as quais podem ser enriquecidas com recursos em outras línguas e campos. A viagem termina com reflexões a respeito das complexas relações de poder que requerem meticulosa atenção por parte dos profissionais que pretendem promover justiça ocupacional.

Palavras-chave: Reflexividade Crítica, Geração de Conhecimento, Ciência Ocupacional, Prática Profissional.

Corresponding author: Elizabeth Townsend, Dalhousie University, School of Occupational Therapy, Forrest Building Room 215 , 5869 University Avenue, Halifax, Nova Scotia, Canada, B3H 3J5, e-mail: liz.townsend@ dal.ca Received on 4/19/2013; Accepted on 5/20/2013. 
Where everyday injustice - occupational injustice - persists, health and social professionals have an ethical, moral and professional obligation to reduce injustice with and for destitute as well as privileged members of society. But can professionals actually enable occupational justice? This reflective paper takes readers on a journey toward optimistically responding maybe. The analytic approach is summarized in preparation for tracing when and how the awakening to occupational injustice began. The journey continues by highlighting resources - namely a YouTube film: Reaching Out: Today's Activist Occupational Therapy and selected English language references from occupational science and occupational therapy that display an emerging knowledge bank for six areas of population-based occupational justice practice, or the social occupational therapy practices in South America (GALHEIGO, 2011a). The potential for knowledge generation to enrich this bank is unlimited in many fields and languages. The journey ends with reflections on the complex professional power relations that need careful attention by professionals who intend to enable occupational justice.

Before tracing the awakening to occupational injustice, the paper orients readers to the critically reflexive thinking inspired particularly by Dorothy Smith's $(2005,2006)$ institutional ethnography (IE), although the paper does not report a specific institutional ethnography. Congruent with IE, the journey starts from an awareness that all humans have a bodily, everyday world standpoint of knowing many occupations when occupation is defined broadly as everything individuals, groups, or communities experience everywhere, anytime in occupying life (e.g., CLARK, 1997; HASSELKUS, 2002; WILCOCK, 1993, 1998a), rather than limiting the definition to objectified categories of work in economic or government statistics as is typical around the world (JARMAN, 2010). The primary interests of this journey are in social change to reduce everyday injustice, not in the justice of punishment or individualized practices with individuals who seek new meanings in occupations (BORELL et al.; 2012; HASSELKUS, 2002) when their personal lives feel unjust. Reflections on actually enabling occupational justice leave concerns for evidencebased practice to others who may be interested in measuring injustice against biomedical markers of occupations (MERNAR, 2006) or evaluating the outcomes of occupation-based projects (ARTHUR; LALANDE, 2009). Instead, the paper traces the awakening to occupational injustice and profiles selected resources to raise consciousness (FREIRE,
1985) and prompt epistemic reflexivity (BOURDIEU; WACQUANT, 1992). Reflexivity is encouraged to consider ideological intentions such as enabling occupational justice in light of institutional relations of ruling (SMITH, 2006) that govern how and why professionals may or may not actually enable occupational justice. From a bodily, everyday world standpoint of knowing occupations, critically reflexive questions about professionals enabling occupational justice could be: How do professions integrate (or not) conceptual theories in real practice situations? Why might professionals intend (or not intend) to enable occupational justice when they are not actually funded or accountable in documented evidence, such as workload statistics, for reducing occupational injustice? How, where and when might professionals work together with populations (collaborate) in enabling justice and what are the challenges? What might professionals actually do in education, housing, employment or other institutions (SMITH, 2006) to change policies, funding and laws that contribute to the routine organization of both occupational injustice and professional practices.

\section{Awakening to occupational injustice}

One can trace the awakening to occupational injustice to the vast literature on related concepts including (but not limited to) participation, health, citizenship, power, empowerment, client-centred practice, risk, and social change. In brief, research over the last century has grown with evidence and critiques of a strong relationship between participation in the everyday world and individual and public health (WORLD..., 1986). For over 30 years, research from an occupational perspective of health has been examining how health can be influenced by and influences what people do in the everyday world (e.g., CHRISTIANSEN; TOWNSEND, 2010; WHITEFORD; WRIGHT-ST CLAIR, 2005; WILCOCK, 1993, 1998a, 2005a; WILCOCK; TOWNSEND, 2014). Furthermore, the past decades have seen volumes of health and other research exploring relationships between the concepts of participation, health and citizenship with critiques of power that suggest greater effectiveness when professionals engage in doing with participants (e.g., patients, clients, communities, populations, residents) rather than doing to or for those who engage in professional services (ASTON et al., 2009; TOWNSEND, 1998a; WILCOCK, 1998a). In the last decade, consciousness raising and critical reflection from an occupational perspective has 
continued, for instance, questioning the influences of occupations on physical, mental and spiritual health (e.g., BRYANT, 2010; BRYANT et al., 2011; MARMOT et al., 2012; PRODINGER et al., 2012; PUUMALAINEN, 2011; WILCOCK, 2006; WILSON et al., 2008).

In addition, centuries of literature on citizenship exist, profiling global awareness that civic involvement (WORLD..., 1986) benefits health when people are challenged, empowered and engaged to participate in something that transcends individual problems (FOX; QUINN, 2012; FOSTER-FISHMAN; PIERCE; VAN EGEREN, 2009; BESS et al., 2009; WORLD..., 1998). Explorations of an occupational perspective of citizenship have covered broad ranging ideas about reducing injustice, as in the collected papers of Occupational Therapy Without Borders: Towards an Ecology of Occupation-Based Practices (KRONENBERG; POLLARD; SAKELLARIOU, 2011). Critical analyses of society emphasize that the impacts of participation and citizenship on health depend greatly on what are called social determinants of health, such as education, income or social support networks (MARMOT et al., 2012; RAPHAEL; CURRY-STEVENS, 2009). It is known that social determinants of health are managed through social institutions (SMITH, 2006) that are governed by conceptual practices of power. Power is embedded conceptually in policies, funding and laws that actually regulate what can be done (SMITH, 1990). For example, funding and municipal housing bylaws may encourage high cost housing development governed by the concept of neighbourhood improvement, despite urgent needs for affordable housing for low income residents (TOWNSEND et al., 2009). Said another way, institutional policies and other governance create, perpetuate, and normalize the exclusion of particular groups who do not easily fit in society (PEREIRA; WHITEFORD, 2012).

The global awakening to restricted participation, limited citizenship and social exclusion for some more than others is congruent with the awakening to occupational injustice in the fields of occupational science and occupational therapy. From occupational science beginnings in the United States and Australia over 30 years ago (YERXA et al., 1990; ZEMKE; CLARK, 1996; WILCOCK, 1993), a renaissance of interest in occupation (WHITEFORD; TOWNSEND; HOCKING, 2000) has lead to interdisciplinary perspectives on occupation, increasingly with visionary ideas and explicit moral and global interests (FRANK, 2012; RUDMAN et al., 2008).
The awakening to actually publish occupational injustice as new occupational science terminology occurred in an international dialogue between the first author and Dr. Ann Wilcock on visions of a more occupationally just world (WILCOCK; TOWNSEND, 2000, TOWNSEND; WILCOCK, 2004a). When they met serendipitously in Australia, Wilcock (1993, 1998a, b) had been developing an occupational perspective of health, participation, citizenship, justice and occupational deprivation (HOCKING, 2012). In Canada, Townsend (1993, $1998 \mathrm{a}, \mathrm{b})$ had been raising critical analyses of the institutional relations of power that shape whether or not professionals can enable empowerment and social justice through so-called client-centred engagement in occupations. Together, they began to present and publish on the related concepts of occupational justice and injustice

[...] to bring to public awareness the injustices that persist when participation in occupations is barred, confined, restricted, segregated, prohibited, undeveloped, disrupted, alienated, marginalized, exploited, excluded or otherwise restricted (TOWNSEND; WILCOCK, 2004a, p. 77).

Simply stated, the concepts of occupational justice and injustice offered a new language and set of beliefs, values, and ideas to explore conditions that restrict everyday participation and citizenship in what Wilcock described conceptually as doing, being, becoming and belonging through occupation (WILCOCK, 1998a, b, 2006; TOWNSEND; WHITEFORD; HOCKING, 1998; TOWNSEND; WILCOCK, 2004b). With recognition of the problematic reference to occupation and the complexities of justice, the thinking about occupational injustice prompted ideas about restricted participation in situations that limit doing the performance of actual occupations - for instance because of limited funding, rigid policies or other forces beyond the limitations of bodily impairments ${ }^{1}$. Restricted participation was also recognized as occurring in situations that limit being and becoming fully human through engagement in everyday occupations that touch the individual or collective human spirit and stimulate a sense of meaning. In addition, everyday experiences of injustice were recognized in situations where institutional (systemic) conditions routinely restrict some people from belonging as they attempt to participate and be included in the typical occupations of a society.

The awakening to occupational injustice beyond social injustice was to identify the occupational 
disparities of particular populations. Knowing that dialogues on this matter need to continue, Stadnyk, Townsend and Wilcock (2010) clarify the point of divergence between occupational and social justice as different points of advocacy. Whereas social justice advocates for "equitable access to opportunities and resources to reduce group differences" (p. 347), occupational justice advocates for "[...] different access to opportunities and resources to acknowledge individual differences resulting from human biology and human interaction with the natural and human environment." (p. 348). Because occupation and justice need to be defined differently in different contexts, Townsend and Wilcock resisted creating a single definition. They offered instead An Exploratory Theory of Occupational Justice (TOWNSEND; WILCOCK, 2004b, p. 250-251) to prompt dialogue on central beliefs and principles about occupation, justice and injustice.

The standpoint in this paper of knowing occupation as bodily, ordinary, everyday life experiences is another way to articulate the central belief of the Exploratory Theory: the belief that all humans are occupational beings. Belief in the essential, occupational nature of humans extends to the belief that humans participate individually and collectively in occupations as interdependent beings who are also autonomous agents. Living differently in diverse socio-cultural-political contexts, humans experience diverse influences on their education, work, home and other occupations and on the development of their diverse capabilities to participate (KANTARTZIS; MOLINEUX, 2011).

By 2010, the Exploratory Theory (WILCOCK; TOWNSEND, 2004b) had evolved into a Framework of Occupational Justice (STADNYK; TOWNSEND; WILCOCK, 2010) with four outcomes of occupational injustice named to distinguish between occupational imbalance, occupational deprivation, occupational marginalization and occupational alienation (p. 338). Other elements added in the 2010 Framework were major structural and contextual determinants of occupational justice and injustice that resemble the social determinants of health with added concerns when the potential of humans as occupational beings is restricted. Now an exploratory Occupational Justice and Health Questionnaire (OJHQ) (WILCOCK; TOWNSEND, 2014, p. 548-549) is being piloted with a structured, checklist for critical reflection by those interested in enabling occupational justice or occupational rights ${ }^{2}$.

In tracing the awakening to occupational injustice, it is necessary to acknowledge the inspiration drawn from the vast international publications on social justice and human rights, five of which are noted because of their global stature. The General Assembly of the United Nations (UN) Declaration of Human Rights (1948) stands out as a landmark statement of the universal human right to participate in everyday life with full citizenship regardless of ability, culture, old age, race, religion and other differences. The UN Declaration is echoed in many World Health Organization (WHO) initiatives, notably the Ottawa Charter for Health Promotion (WORLD..., 1986, 1998) published almost 40 years after the UN Declaration (1948). In reflecting on the founding ideas about occupational injustice, there is much to learn from the Charter's call to advocate for health as a resource to be achieved in everyday life by all not only those who are privileged in society, to enable the development of a supportive environment for achieving health equity, and to mediate coordinated efforts on the social determinants of health.

Inspiration to explore occupational injustice can also be found in writings by the Pan American Health Organization (PAHO) (2010, September), the world's oldest public health organization since 1902, which has been urging the use of international treaties for advancing the health of vulnerable groups. Within occupational therapy, the World Federation of Occupational Therapists (WFOT) has confirmed this profession's interest in occupational injustice by building official relations with WHO since 1959 and endorsing the UN Declaration of Human Rights. WFOT has publicly endorsed efforts to advance occupational justice in a Position Statement on Human Rights (2006, p. 1) 3 $^{3}$ in which the first principle is that: "people have the right to participate in a range of occupations that enable them to flourish."

A fifth international influence in awakening to occupational injustice has been the Capabilities Approach articulated by Sen $(2005,2009)$ writing on social development and Nussbaum (2003, 2004, 2006, 2007) writing on the Human Capabilities Framework. There seems to be a strong convergence in that both occupational and capabilities frameworks of justice emphasize the need for human engagement in everyday life to develop capabilities. They both draw lessons for structural changes that can advance social as well as economic development through social accountability, governance to promote social inclusion, and universal rights (TOWNSEND, 2012). The divergence is in the organization and language of these frameworks that originate in different bodies of research. Analyses in the literature that use the Occupational Justice Framework revolve around the 
four types of restricted occupational participation: occupational alienation, occupational deprivation, occupational imbalance, and occupational marginalization, plus occupational apartheid (KRONENBERG; POLLARD; SAKELLARIOU, 2011). Analyses using the Human Capabilities Framework revolve around extensive critique of the ethical, moral, social and economic conditions for being fully human.

In summary, the awakening to occupational injustice to date has been to name this and related concepts, and to explore central beliefs, values and ideas from occupational science and international sources. Inspiration has been particularly helpful from UN, WHO, PAHO and WFOT and Human Capabilities Framework documents on wide ranging topics from participation to human rights.

\section{Resources for developing occupational justice practices}

One suggested stimulus for developing occupational justice practices is a visual resource - a YouTube film, Reaching Out: Today's Activist Occupational Therapy (TOWNSEND; SANDIFORD, 2012) ${ }^{4}$. The film illustrates two practices with historical commentary (FRIEDLAND, 2011) on the activist foundations of Canadian occupational therapy. Without naming occupational justice or injustice, the film profiles one occupational therapy practice that emphasizes experiential learning through doing in a Nova Scotian primary health care street health program. It illustrates occupationbased approaches to participation, citizenship, and learning with street participants. The other practice profiles a leadership initiative in connecting systems, called institutions in this paper, to coordinate community, professional and government responses to severe mental health, school absenteeism, legal, and addiction issues of a segment of youth across Canada's Nunavut Territory. Dialogue sparked by the film could take many directions, one of which might be to critically reflect on, adapt or build on the two practices.

Another suggested stimulus is to gather literature to enrich dialogue on the film or other resources. An online search was done through World Cat to find English titles or abstracts, mainly in peer-reviewed journal articles but also in occupational therapy practice newsletters using the keywords occupational justice or occupational injustice, with a diversion to track down the early papers on occupational deprivation and current occupational therapy books. It will be obvious to readers who know of global, justice-based research and projects, that literature searches, largely using two keywords in peer-reviewed journal articles, are merely a starting place, and that the search for this paper may have missed important contributions. Additional keyword or hand searching for reports, books and other documentation in any field and language could deepen the search reported here. A more extensive occupational justice search could include keywords that in English or other languages speak to concerns for routine, everyday injustice expressed in a Western context as occupational deprivation, occupational alienation, occupational imbalance, occupational marginalization, capacity development, social justice, social change, critical or radical practice, community development and more.

One outcome of the search has been to collate the three most accessible online, occupational justice practice frame works linking theory and practice. The most developed of these (DUROCHER; GIBSON; RAPPOLT, 2013), the Participatory Occupational Justice Framework (POJF) (WHITEFORD; TOWNSEND, 2011), uses a visual model as a framework to display a 6-point, interconnected practice process of critical occupational therapy for creating collaborative, participatory decision-making opportunities for advancing social inclusion and justice. Wolf et al. (2010) developed a chart as a practitioner-friendly Framework for Addressing Issues of Occupational Justice. The chart shows how practitioners might advocate for policy change after starting with individuals, their example being a 61 year-old man referred to a Geriatric Day Centre whose situation prompted practitioners to press for policy changes in the Centre. The most recent framework is a checklist called the Conceptual Framework of Assistive Technology and Occupational Justice (ARTHANAT et al., 2012, p. 315). The checklist can be used to identify access to the assistive technology that individuals or groups need to participate in their desired occupations.

The other search outcome is collated in Table 1. The process of reflecting on and collating the search results gave rise to the idea of an emerging knowledge bank that could bring a new occupational justice perspective to old problems of injustice. The naming of populations in Table 1 was based partly on the numbers of papers found, and partly on the potential for occupational justice practices to show professional responsiveness and leadership to collaborate with global populations who experience persistent social and economic challenges. Occupational injustice issues and responses are summarized for six populations: persons with a disability, persons 
Table 1. An Emerging Knowledge Bank for Population-Based Occupational Justice Practices.

\section{Can Professionals Actually Enable Occupational Justice?}

1. What might professionals actually do in education, employment, health, housing, transportation or other institutions (SMITH, 2006) to change policies, funding and laws that contribute to the routine, takenfor-granted organization of occupational injustice and professional practices?

2. How, where and when might professionals work together with populations (collaborate) in enabling justice and what are the challenges?

Occupational Justice Practices with Persons with a Disability

Occupational injustice for persons with a disability persists in communities, hospitals, and other settings that may fail to attend sufficiently to culturally-appropriate occupations, the right to work with or without accommodations, access to required assistive technologies, or violence against women.

Occupational justice practices might design policies, funding, legislation and programs in collaboration with, not for, persons with a disability and with non-governmental organizations, government and other professional colleagues and families. Examples are practices to: ensure health services reflect culturally-appropriate occupations; guarantee employment support strategies; create inclusive access to assistive technology and home and workplace modifications; sanction professional advocacy for the right to work with a disability; design accountability systems for collective activism to reduce violence against women with disabilities. "These actions need not be grand but rather can be small and incremental steps that are context specific and work towards the larger goal of occupational justice." (WOLF et al., 2010, p. 17).

(ARTHANAT et al., 2012; BALCAZAR; KEYS; SUAREZ-BALCAZAR, 2001; GALVIN; WILDING; WHITEFORD, 2011; HAMMELL, 2008; JAKOBSEN, 2004; KRAMER-ROY, 2011; SAKELLARIOU; SIMÓ ALGADO, 2006; SMITH; HILTON, 2008; WILDING; WHITEFORD, 2008; WOLF et al., 2010).

Occupational Justice Practices with People Living in Poverty

Occupational injustice persists for those who live in poverty and/or homelessness and for those experiencing major cultural changes in difficult economic circumstances, or in occupational transitions, such as the transition from being a youth in foster care to becoming an autonomous adult.

Occupational justice practices might include to collaborate with local and government representatives to develop population capacity across all age groups; funding, policies, and initiiatives for education, child development, employment, housing, transportation, etc. "Local energy, commitment, and expertise are the critical factors that drive capacity development." (VAN BRUGGEN, 2011, p. 302).

(BARROS et al., 2011; CZYMONIEWICZ-KLIPPEL, 2011; GALHEIGO, 2011; KRAMER-ROY, 2011; PAGANIZZI; MENGELBERG, 2011; PAUL WARD, 2009; SIMÓ, 2011; TOWNSEND; SANDIFORD, 2012; VAN BRUGGEN, 2011).

Occupational Justice Practices with People in Disaster, War and Refugee Zones

Occupational injustice persists for peoples anywhere who live as refugees or immigrants after fleeing from oppression, violence or loss of land in the case of disaster or war zones.

Occupational justice practices might design and coordinate programs with refugees, immigrants and others, to develop: sustainability in routines and habits; new projects with choice, decision-making and engagement in meaningful occupations within restricted space and funding; new collective activism to challenge restricted funding and support workers. "[...] opportunities for joining, sharing and cultural expression through a range of activities that brought him into contact with others was especially important." (WHITEFORD, 2005, p. 86).

(BLACK, 2011; HUDSON; AOYAMA, 2011; RUSHFORD; THOMAS, 2011; THIBEAULT, 2002, 2011; WHITEFORD; WRIGHT-ST CLAIR, 2005).

\section{Occupational Justice Practices with Seniors}

Occupational injustice persists in limited social inclusion due to restrictive, and over-protective housing, lack of age-friendly transportation and technology, insufficient income assistance, and 'keep busy' activities in residential care.

Occupational justice practices might design inclusive policies, social accountability and rights with older people, for example: affordable community programs, flexible housing options to sustain maximum capabilities; programs with indoor and outdoor occupations for socializing, productivity and civic participation; activism for senior-friendly transportation, technology, and income assistance; and, integrated or target programs that consider social class, ethnicity (especially language), gender, race, sexual orientation, etc. "Intervention should address more than just the remediation of skills and abilities." (BERGER et al., 2012, p. 3).

(BERGER et al., 2012; BROWN, 2008; FOX; QUINN, 2012; NILSSON; TOWNSEND, 2010; STADNYK, 2007; WILCOCK, 2005b). 
Table 1. continuation...

Occupational Justice Practices Related to Class, Gender, Race or Sexual Orientation

Occupational injustice persists in the hegemony of the dominant social order in which professionals may ignore the sexual occupations of men with disabilities, the occupations of transgendered people, or the race-based challenges of women and foster children.

Occupational justice practices might design and implement policies, funding, legislation and programs with representatives of social groups, for example: raise awareness and take action on gender, sexual orientation, transgender and social class issues in hospitals and society; support engagement in spiritual occupations to counter racism; develop interdisciplinary projects that acknowledge social difference related to gender, race and class; and, move professional practices from individualized to contextual approaches." [transgendered people] faced both occupational losses, such as parenting roles and religious occupations, but also gained new, meaningful occupations, including social and political activism." (BEAGAN et al., 2012, p. 238). (ANGELL, 2012; BEAGAN; ETOWA, 2011; BEAGAN et al., 2012).

\section{Occupational Justice Practices Related to Incarceration}

Occupational injustice persists for prisoners who are isolated and deprived of the occupations they need to sustain their physical, mental and spiritual health, or who lack probation support services for community re-integration.

Occupational justice practices might design and coordinate advocacy for prisoner access to occupations such as self-maintenance that would prepare them for community living; and, work-based and community living programs might collaborate with probation services to support sustainable community life. "Stress could be alleviated, and at the same time skill development encouraged, by making only subtle changes to the prison environment. One way might be to give inmates greater responsibility for self-maintenance." (MOLINEUX; WHITEFORD, 1999, p. 129).

(MOLINEUX; WHITEFORD, 1999; MUÑOZ et al., 2011; WHITEFORD, 1997).

living in poverty, persons in disaster, war and refugee zones, seniors, persons who differ from the social 'norm' of class, gender, race, religion, or sexual orientation, and persons who are currently or have been recently incarcerated ${ }^{5}$.

\section{An emerging knowledge bank for population-based occupational justice practices}

Readers are invited to look at Table 1 with critical reflection on their own bodily, everyday world standpoint of knowing occupations, asking: What examples of occupational justice and injustice are known to be routine parts of everyday life? This opening reflection can be used to refine or add to the occupational injustice issues summarized in Table 1. The references listed to guide collaboration with each population in Table 1 seem to particularly invite dialogue and action on two questions about occupational justice practices: What might professionals actually do in education, employment, health, housing, transportation or other institutions (SMITH, 2006) to change policies, funding and laws that contribute to the routine organization of occupational injustice and professional practices? How, where and when might professionals work together with populations (collaborate) in enabling justice and what are the challenges?

\section{Discussion - taking a radical turn}

The journey travelled in this paper ends with reflections on the complex professional power relations that need careful attention by those who intend to enable occupational justice. (TOWNSEND; POLATAJKO, 2013) Can professionals actually enable occupational justice? One could glibly answer no given a history of professional dominance, with professional expertise prevailing over other ways of knowing (BELENKY et al., 1986; FREIDSON, 1986; SMITH, 2006). Professionals, including occupational therapists (ABBERLEY, 1995), have been critiqued for disabling or oppressing practices (ILLICH et al., 2010; FREIRE, 1972, 1985). In their education, professionals are socialized to fit in with the prevailing professional discourse, rules and regulations that normalize a docile professional (MACKEY, 2011). Professionals face the contradictions of being insiders whose work supports the very same relations of ruling that their activism is targeting to change (MURRAY, 2012; RAVENSBERGEN; VANDERPLAAT, 2009; SMITH, 1990). In working with community-based groups on social change, professionals experience the pitfall of needing to use existing funding and regulations that actually reproduce the existing social order (MYKHALOVSKIY; McCOY, 2012). 
Alternately one can answer maybe professionals can enable occupational justice - with a radical turn to use professional power in social practices aimed at reducing marginality, exclusion, apartheid, disaffiliation, vulnerability, and deprivation (GALHEIGO, 2011a) and political practices aimed at policy, funding and legal changes (KRONENBERG; SIMÓ ALGADO, 2003; BARBARA; WHITEFORD, 2005). A strong community of activist practitioners need to engage in raising critical consciousness and civic courage (FREIRE, 1985, 1989, 1998) and in creating a regulatory context compatible with enabling occupational justice (MURRAY, 2012; WHITEFORD, 2007; WHITEFORD; TOWNSEND, 2011). Reflection-based, popular education may offer a strategy to reveal taken-forgranted injustice (BOURDIEU; WACQUANT, 1992; KINSELLA; WHITEFORD, 2009) and the social conditions "[...] through which people who have been alienated from their culture are encouraged to identify, examine and act on their root causes of oppression." (CARROLL; MINKLER, 2000, p. 23) as a precursor for social change (BRASHERS et al., 2002, p. 114 quoted in FOX; QUINN, 2012, p. 359). In individualized health and social contexts, it has already been recognized that efforts at social change

[...] should concentrate on overcoming the extrinsic factors hindering participation in leisure, such as transport difficulties and financial limitations, and enabling socialising and networking. (PIERIS; CRAIK, 2004, p. 246).

Taking a radical turn could mean organizing inter-professional activism and critical practices, (GALHEIGO, 2011b; HAMMELL; IWAMA, 2012; WHITEFORD; TOWNSEND, 2011) to influence what has been called the small "p" politics" of communities or nations (KRONENBERG; SIMÓ ALGADO, 2003; POSTLE; WRIGHT; BERESFORD, 2005). Inter-professional collaboration could

[...] build structural/organizational transparent lines of communication [...] clarify common goals [...] set aside time for team-building for establishing joint activities for members of different agencies, and for developing shared protocols and documentation. (ROBINSON; COTTRELL, 2005, p. 557).

Other actions could be writing opinions, meeting to persuade others to join actions (GORDON, 2002a, b), and developing local capabilities through projects aimed at advancing justice (VAN BRUGGEN, 2011).
There are so many avenues to continue the awakening to occupational injustice and to occupational justice practices. Theoretically, there is a need to extend the exploration of ethical, moral and philosophic ideas inherent in the concept of occupational justice, and critical/radical leadership is needed to apply the concept in practice, as suggested in a thoughtful conceptual review of occupational justice (DUROCHER; GIBSON; RAPPOLT, 2013) and a proposal for future directions (DUROCHER; RAPPOLT; GIBSON, 2013). Other steps in awakening to occupational injustice could be to collect and analyze stories and images of persistent injustice that could help in distinguishing between social and occupational injustice. An occupational justice research perspective (RICHARDSON; MACRAE, 2011) could examine the relationship between occupational and social injustice, and could generate critiques, ideas and practice applications with the populations of concern to particular professional teams. Inter-professional collaboration could be particularly fruitful with those from community health, community development, ecology, economics, law, non-governmental organizations, political science, social work, and other fields. Stories told by people who experience injustice would greatly enrich dialogues on how and why professionals may or may not actually enable occupational justice.

\section{Concluding reflections}

Can professionals actually enable occupational justice? The response developed in this paper is maybe. The thinking behind this response has been to briefly trace the awakening to occupational injustice and to collate selected English language resources to guide occupational justice practices. The literature search suggests an emerging knowledge bank for occupational justice practices that could respond to routine injustice experienced by six populations. The populations were named to reflect the volume of literature found and the global concern for the social and economic challenges associated with these populations. The closing discussion of professional power and inter-professional collaboration is intended to launch the leadership journeys needed for actually enabling occupational justice (TOWNSEND et al., 2011).

\section{Acknowledgements}

The authors celebrate those who have been instrumental in launching the journey to understand occupational justice and apply this concept in practice. Gratitude is extended specifically to 
participants in the YouTube film Reaching Out: Today's Activist Occupational Therapy. Cathy McNeil was at the time the Territorial Rehabilitation Coordinator, Department of Health and Social Services, Government of Nunavut in Iqaluit. Judith Friedland is Professor Emerita, Department of Occupational Science and Occupational Therapy University of Toronto. Mark Sandiford is a documentary filmmaker and owner of Beachwalker Films Inc., Prince Edward Island. Filip Dejonckheere (Ghent), Johanna Stadler-Grillmaier (Vienna), Soemitro Poerbodipoero (Amsterdam), Salvador Simó Algado (Vic, Spain) and Hanneke van Brugggen (Apeldoorn, Netherlands) are acknowledged for valuable comments on the authors' March 2013 presentations onsite with their students and colleagues on Inter-professional Occupational Justice Practices.

\section{References}

ABBERLEY, P. Disabling ideology in health and welfare - the case of occupational therapy. Disability and Society, London, v. 10, p. 221-232, 1995.

ANGELL, A. M. Occupation-centered analysis of social difference: contributions to a socially responsive occupational science. Journal of Occupational Science, Melbourne, v. 79, n. 5, p. 309-319, 2012. http://dx.doi. org/10.2182/cjot.2012.79.5.7

ARTHANAT, S. Exploring occupational justice in consumer perspectives on assistive technology. Canadian Journal of Occupational Therapy, Thousand Oaks, v. 79, p. 309, 2012. http://dx.doi.org/10.1007/s10447-008-9063-z ARTHUR, N.; LALANDE, V. Diversity and social justice implications for outcome approaches to evaluation. International Journal for the Advancement of Counselling, The Hague, v. 31, n. 1, p. 1-16, 2009. http://dx.doi. org/10.1080/07370010802605762

ASTON, M. et al. Public health nurses' primary health care practice: strategies for fostering citizen participation. Journal of Community Health Nursing, Philadelphia, v. 26, p. 24-34, 2009. http://dx.doi. org/10.1080/07370010802605762

BALCAZAR, F. E.; KEYS, C. B.; SUAREZ-BALCAZAR, Y. Empowering Latinos with disabilities to address issues of independent living and disability rights: a capacitybuilding approach. Journal of Prevention \& Intervention in the Community, Melbourne, v. 21, n. 2, p. 53-70, 2001. http://dx.doi.org/10.1300/J005v21n02_04

BARBARA, A.; WHITEFORD, G. The legislative and policy context of practice. In: WHITEFORD, G.; WRIGHT-ST CLAIR, V. (Ed.). Occupation and practice in context. Merrickville: Elsevier, 2005. p. 332-348.

BARROS, D. D. et al. Brazilian Experiences in Social Occupational Therapy. In: KRONENBERG, F.; POLLARD, N.; SAKELLARIOU, D. (Ed.). Occupational therapy without borders: towards an ecology of occupation-based practices. London: Elsevier Press, 2011. v. 2, p. 209-215.

BEAGAN, B. L.; ETOWA, J. B. The meanings and functions of occupations related to spirituality for African Nova Scotian women. Journal of Occupational Science, Melbourne, v. 18, p. 277-229, 2011. http://dx.doi.org/1 $0.1080 / 14427591.2011 .594548$

BEAGAN, B. L. et al. "This is the biggest thing you'll ever do in your life": exploring the occupations of transgendered people. Journal of Occupational Science, Melbourne, v. 19, n. 3, p 226-240, 2012. http://dx.doi. org/10.1080/14427591.2012.659169

BELENKY, M. F. et al. Women's ways of knowing: the development of self, voice and mind. New York: Basic Books, 1986.

BERGER, S. et al. Infusing occupational justice into gerontology practice. Gerontology Special Interest Section Quarterly, Basel, Switzerland, v. 35, n. 1, p. 1-6, 2012.

BESS, K. et al. Participatory organizational change in community-based health and human services: from tokenism to political engagement. American Journal of Community Psychology, Washington, v. 43, n. 1, 124-148, 2009. http://dx.doi.org/10.1007/ s10464-008-9222-8

BLACK, M. From kites to kitchens: collaborative community-based occupational therapy with refugee survivors of torture. In: KRONENBERG, F.; POLLARD, N.; SAKELlARIOU, D. (Ed.). Occupational therapy without borders: towards an ecology of occupation-based practices. London: Elsevier Press, 2011. v. 2, p. 217-225. BORELL, L. et al. Qualitative approaches in occupational therapy research. Scandinavian Journal of Occupational Therapy, Oslo, v. 19, n. 6, p. 521-529, 2012. http://dx.doi. org/10.3109/11038128.2011.649782

BOURDIEU, P.; WACQUANT, L. An invitation to reflexive sociology. Chicago: University of Chicago Press, 1992.

BRASHERS, D. et al. Social activism, self-advocacy and coping with HIV illness. Journal of Social and Personal Relationships, London, v. 19, p. 113-133, 2002. http:// dx.doi.org/10.1177/0265407502191006

BROWN, C. A. The implications of occupational deprivation experienced by elderly female immigrants. Diversity in Health and Social Care, London, v. 5, n. 1, p. 65-69, 2008.

BRYANT, W. Guest Editorial: Global voices, local lives: human rights and occupational therapy. World Federation of Occupational Therapists - WFOT Bulletin, Hong Kong, v. 62, p. 5-6, 2010.

BRYANT, W. et al. An occupational perspective on participatory action research. In: KRONENBERG, F.; POLLARD, N.; SAKELLARIOU, D. (Ed.). Occupational therapy without borders: towards an ecology of occupationbased practices. London: Elsevier Press, 2011. v. 2, p. 367-374. 
CARROLL, J.; MINKLER, M. Freire's message for social workers: looking back, looking ahead. Journal of Community Practice, Melbourne, v. 8, n. 1, p. 21-36, 2000.

CHRISTIANSEN, C.; TOWNSEND, E. A. Introduction to occupation: The art and science of everyday living. 2 nd ed. Upper Saddle River: Prentice Hall, 2010.

CLARK, F. Reflections on the human as an occupational being: biological need, tempo and temporality. Journal of Occupational Science, Melbourne, v. 4, n. 3, p. 86-92, 1997. http://dx.doi.org/10.1080/14427591.1997.9686424

CZYMONIEWICZ-KLIPPEL, M. Researching to learn: embracing occupational justice to understand Cambodian children and childhoods. In: KRONENBERG, F.; POLLARD, N.; SAKELLARIOU, D. (Ed.). Occupational therapy without borders: towards an ecology of occupationbased practices. London: Elsevier Press, 2011. v. 2, p. 375-384.

DUROCHER, E.; GIBSON, B. E.; RAPPOLT, S. Occupational justice: a conceptual review. Journal of Occupational Science, Melbourne, 2013. http://dx.doi. org/10.1080/14427591.2013.775692

DUROCHER, E.; RAPPOLT, S.; GIBSON, B. E. Occupational justice: future directions. Journal of Occupational Science, Melbourne, 2013. http://dx.doi. org/10.1080/14427591.2013.775693

FOSTER-FISHMAN, P.; PIERCE, S.; VAN EGEREN, L. Who participates and why: building a process model of citizen participation. Health Education \& Behavior, Thousand Oaks, v. 36, n. 3, p.550-569, 2009. http:// dx.doi.org/10.1177/1090198108317408

FOX, J.; QUINN, S. The meaning of social activism to older adults in Ireland. Journal of Occupational Science, Melbourne, v. 19, n. 4, p. 358-370, 2012. http://dx.doi. org/10.1080/14427591.2012.701179

FRANK, G. The 2010 Ruth Zemke Lecture in Occupational Science. Occupational therapy/occupational science/occupational justice: moral commitments and global assemblages. Journal of Occupational Science, Melbourne, v. 19, n. 1, p. 25-35, 2012. http://dx.doi. org/10.1080/14427591.2011.607792

FREIDSON, E. Professional powers: a study of the institutionalizaton of formal knowledge. Chicago: University of Chicago Press, 1986.

FREIRE, P. Pedagogy of the oppressed. New York: Seabury Press, 1972.

FREIRE, P. The politics of education: culture, power and liberation, transl. by D. macedo. South Hadley: Bergin \& Garvey, 1985.

FREIRE, P. Education for critical consciousness. New York: Continuum, 1989.

FREIRE, P. Pedagogy of freedom, ethics, democracy and civic courage. Lanham: Rowman \& Littlefield, 1998.

FRIEDLAND, J. Restoring the spirit: the beginnings of occupational therapy in Canada, 1890-1930. [s.l.]: McGill-Queens University Press, 2011.

GALHEIGO, S. M. Occupational therapy in the social field: concepts and critical considerations. In:
KRONENBERG, F.; POLLARD, N.; SAKELLARIOU,

D. (Ed.). Occupational therapy without borders: towards an ecology of occupation-based practices. London: Elsevier Press, 2011a. v. 2, p. 47-56.

GALHEIGO, S. M. What needs to be done? Occupational therapy responsibilities and challenges regarding human rights. Australian Occupational Therapy Journal, Melbourne, v. 58, p. 60-66, 2011b. http://dx.doi. org/10.1111/j.1440-1630.2011.00922.x

GALVIN, D.; WILDING, C.; WHITEFORD, G. Utopian visions/dystopian realities: exploring practice and taking action to enable human rights and occupational justice in a hospital context. Australian Occupational Therapy Journal, Melbourne, v. 58, p. 378-385, 2011. http://dx.doi.org/10.1111/j.1440-1630.2011.00967.x

GENERAL ASSEMBLY OF THE UNITED NATIONS. Universal Declaration of Human Rights. [s.l.]: Department of Public Information, 1948. Disponível em: <http://www. un.org/Overview/rights.html>. Acesso em: 27 abr. 2006. GORDON, G. Advocacy toolkit: practical action in advocacy. Teddington: Tearfund. Roots Resources, 2002a.

GORDON, G. Advocacy toolkit: understanding advocacy. Teddington: Tearfund. Roots Resources, 2002b.

HAMMELL, K. W. Reflections on... well-being and occupational rights. Canadian Journal of Occupational Therapy, Thousand Oaks, v. 75, p. 61-64, 2008.

HAMMELL, K. W.; IWAMA, M. Well-being and occupational rights: An imperative for critical occupational therapy, Scandinavian Journal of Occupational Therapy, Oslo, v. 19, p. 385-394, 2012. http://dx.doi.org/10.310 9/11038128.2011.611821

HASSELKUS, B. The meaning of everyday occupation. Thorofare: Slack, Inc., 2002.

HOCKING, C. Working for citizenship: The dangers of occupational deprivation. Work, Reading, v. 41, p. 391-395, 2012.

HUDSON, M.; AOYAMA, M. Occupational apartheid and national parks: the Shiretoko World Heritage Site. In: KRONENBERG, F.; POLLARD, N.; SAKELLARIOU, D. (Ed.). Occupational therapy without borders: towards an ecology of occupation- based practices. London: Elsevier Press, 2011. v. 2, p. 246-256.

ILLICH, I. et al. Disabling professions. 3rd ed. London: Marion Boyars, 2010.

JAKOBSEN, K. If work doesn't work: how to enable occupational justice. Journal of Occupational Science, Melbourne, v. 11, n. 3, p. 125-134, 2004.

JARMAN, J. What is occupation? interdisciplinary perspectives on defining and classifying human activity. In: CHRISTIANSEN, C.; TOWNSEND, E. A. Introduction to occupation: The art and science of everyday living. 2nd ed. Upper Saddle River: Prentice Hall, 2010. p. 81-99.

KANTARTZIS, S.; MOLINEUX, M. The influence of Western society's construction of a healthy daily life on the conceptualisation of occupation. Journal of Occupational 
Science, Melbourne, v. 18, n. 1, p. 62-80, 2011. http:// dx.doi.org/10.1080/14427591.2011.566917

KINSELLA, A.; WHITEFORD, G. Knowledge generation and utilisation in occupational therapy: towards epistemic reflexivity, Australian Occupational Therapy Journal, Melbourne, v. 56, p. 249-258, 2009. http://dx.doi. org/10.1111/j.1440-1630.2007.00726.x

KRAMER-ROY, D. Occupational injustice in Pakistani families with disabled children in the UK: A PAR study. In: KRONENBERG, F.; POLLARD, N.; SAKELLARIOU, D. (Ed.). Occupational therapy without borders: towards an ecology of occupation-based practices. London: Elsevier Press, 2011. v. 2, p. 385-392.

KRONENBERG, F.; POLLARD, N.; SAKELLARIOU, D. (Ed.). Occupational therapy without borders: towards an ecology of occupation-based practices. London: Elsevier Press, 2011.

KRONENBERG, F.; SIMÓ ALGADO, S. The political nature of occupational therapy. Linkoping: University of Linkoping, 2003.

MACKEY, H. Foucault, power and professional identities. In: KRONENBERG, F.; POLLARD, N.; SAKELLARIOU, D. (Ed.). Occupational therapy without borders: towards an ecology of occupation-based practices. London: Elsevier Press, 2011. v. 2, p. 133-141.

MARMOT, M. et al. WHO European review of social determinants of health and the health divide. Lancet, London, v. 380, n. 9846, p. 1011-1029, 2012. http:// dx.doi.org/10.1016/S0140-6736(12)61228-8

MYKHALOVSKIY, E.; McCOY, L. P. Troubling ruling discourses of health: using institutional ethnography in community-based research. Critical Public Health, Melbourne, v. 12, n. 1, p. 17-37, 2012. http://dx.doi. org/10.1080/09581590110113286

MERNAR, T. Occupation, stress, and biomarkers: measuring the impact of occupational injustice. Journal of Occupational Science, Melbourne, v. 13, p. 209-213, 2006. http://dx.doi.org/10.1080/14427591.2006.9726517

MOLINEUX, M.; WHITEFORD, G. Prisons: From occupational deprivation to occupational enrichment. Journal of Occupational Science, Melbourne, v. 6, n. 3, p. 124-130, 1999. http://dx.doi.org/10.1080/14427591 .1999 .9686457

MUÑOZ, J. P. et al. Crossing borders in correctional institutions. In: KRONENBERG, F.; POLLARD, N.; SAKELLARIOU, D. (Ed.). Occupational therapy without borders: towards an ecology of occupation-based practices. London: Elsevier Press, 2011. v. 2, p. 235-246.

MURRAY, K. Regulating activism: an institutional ethnography of public participation. Community Development Journal, London, v. 4, n. 2, p. 199-215, 2012. http://dx.doi.org/10.1093/cdj/bsr022

NILSSON, I.; TOWNSEND, E. A. Occupational justice - bridging theory and practice. Scandinavian Journal of Occupational Therapy, Oslo, v. 1, n. 1, p. 57-63, 2010. http://dx.doi.org/10.3109/11038120903287182
NUSSBAUM, M. Capabilities as fundamental entitlements: Sen and social justice. Feminist Economics, London, v. 9, n. 2-3, p. 33-59, 2003. http://dx.doi. org/10.1080/1354570022000077926

NUSSBAUM, M. C. Beyond the social contract: capabilities and global justice. Oxford Development Studies, Oxfordshire, v. 32, n. 1, p. 3-18, 2004.

NUSSBAUM, M. Frontiers of justice: Disability, nationality, species membership. Cambridge: Harvard University Press, 2006.

NUSSBAUM, M. Frontiers of justice. disability, nationality, species membership. Scandinavian Journal of Disability Research, Oslo, v. 9, n. 2, p. 133-136, 2007. http://dx.doi.org/10.1080/15017410601003171

PAGANIZZI, L.; MENGELBERG, E. G. Argentina: social participation, activities, and courses of action. In: KRONENBERG, F.; POLLARD, N.; SAKELLARIOU, D. (Ed.). Occupational therapy without borders: towards an ecology of occupation-based practices. London: Elsevier Press, 2011. v. 2, p. 227-233.

PAN AMERICAN HEALTH ORGANIZATION PAHO. Countries to promote access to health care as a human right: international treaties are valuable tools for advancing the health of vulnerable groups. News Release on PAHO's 50th Directing Council blog. Disponível em: <http://new.paho.org/blogs/cd50/index.php?lang=en>. Acesso em: 12 nov. 2010.

PAUL WARD, A. Social and occupational justice barriers in the transition from foster care to independent adulthood. American Journal of Occupational Therapy, New York, v. 63, n. 1, 81. 2009. http://dx.doi.org/10.5014/ajot.63.1.81 PEREIRA, R.; WHITEFORD, G. Understanding social inclusion as an international discourse: implications for enabling participation. British Journal of Occupational Therapy, London, v. 76, p. 112-115, 2012. http://dx.doi. org/10.4276/030802213X13603244419392

PIERIS, Y.; CRAIK, C. Factors enabling and hindering participation in leisure for people with mental health problems. British Journal of Occupational Therapy, London, v. 67, n. 6, p. 240-247, 2004.

POSTLE, K.; WRIGHT, P.; BERESFORD, P. Older people's participation in political activity-making their voices heard: a potential support role for welfare professionals in countering ageism and social exclusion. Practice: Social Work in Action, Melbourne, v. 1, n. 3, p. 173-189, 2005. http://dx.doi. org/10.1080/09503150500285123

PRODINGER, B. et al. Arthritis-related occupational therapy: making invisible ruling relations visible using institutional ethnography. British Journal of Occupational Therapy, London, v. 75, n. 10, p. 463-470, 2012. http:// dx.doi.org/10.4276/030802212X13496921049707

PUUMALAINEN, J. Participation in community and political life of persons with severe disabilities. International Journal of Rehabilitation Research, London, v. 34, p. 274-281, 2011. http://dx.doi.org/10.1097/ MRR.0b013e32834a8fc1 
RAPHAEL, D.; CURRY-STEVENS, A. Surmounting the barriers: making action on the social determinants of health a public priority. In: RAPHAEL, D. (Ed.). Social determinants of health. 2 nd ed. Toronto: Canadian Scholars' Press, 2009. p. 362-377.

RAVENSBERGEN, F.; VANDERPLAAT, M. Barriers to citizen participation: the missing voices of people living with low income. Community Development Journal, London, v. 45, n. 4, p. 389-403, 2009. http://dx.doi. org/10.1093/cdj/bsp014

RICHARDSON, P.; MACRAE, A. An occupational justice research perspective. In: KRONENBERG, F.; SIMÓ ALGADO, S.; POLLARD, N. (Ed.). Occupational therapy without borders: Learning from the spirit of survivors. Toronto: Elsevier Churchill Livingstone, 2011. p. 339-348.

ROBINSON, M.; COTTRELL, D. Health professionals in multi-disciplinary and multi-agency teams: changing professional practice. Journal of International Care, Abingdon, v. 19, n. 6, p. 547-560, 2005.

RUDMAN, D. L. et al. A vision for occupational science: reflecting on our disciplinary culture. Journal of Occupational Science, Melbourne, v. 15, p. 136-146, 2008. http://dx.doi.org/10.1080/14427591.2008.9686623

RUSHFORD, N. A.; THOMAS, K. S. Natural disasters: challenging occupational therapists. In: KRONENBERG, F.; POLLARD, N.; SAKELLARIOU, D. (Ed.). Occupational therapy without borders: towards an ecology of occupation-based practices. London: Elsevier Press, 2011. v. 2, p. 185-193.

SAKELLARIOU, D.; SIMÓ ALGADO, S. Sexuality and disability: a case of occupational injustice. British Journal of Occupational Therapy, London, v. 69, n. 2, p. 69-76, 2006.

SEN, A. The idea of justice. Cambridge: Belknap Press of Harvard University Press, 2009.

SEN, A. Human rights and capabilities. Journal of Human Development and Capabilities, Oxford, v. 6, n. 2, p. 151- 166, 2005. http://dx.doi. org/10.1080/14649880500120491

SIMÓ ALGADO, S. Universities and the global change: Inclusive communities, gardening, and citizenship. In: KRONENBERG, F.; POLLARD, N.; SAKELLARIOU, D. (Ed.). Occupational therapy without borders: towards an ecology of occupation-based practices. London: Elsevier Press, 2011. v. 2, p. 357-365.

SMITH, D. E. The conceptual practices of power: a feminist sociology of knowledge. Toronto: Toronto University Press, 1990.

SMITH, D. E. Institutional ethnography: a sociology for people. Walnut Creek: Altima Press, 2005.

SMITH, D. E. Institutional ethnography as practice. New York: Rowman \& Littlefield Publishers, 2006.

SMITH, D. L.; HILTON, C. L. An occupational justice perspective of domestic violence against women with disabilities. Journal of Occupational Science, Melbourne, v. 15, p. 166-172, 2008.
STADNYK, R. Occupational justice. In: COPPOLA, S. et al. (Ed.). Strategies to advance gerontology excellence. Bethesda: AOTA Press, 2007. p. 445-462.

STADNYK, R.; TOWNSEND, E. A.; WILCOCK, A. Occupational justice. In: CHRISTIANSEN, C.; TOWNSEND, E. A. (Ed.). Introduction to occupation: the art and science of living. 2nd ed. Englewood Cliffs: Prentice Hall, 2010. p. 329-358.

THIBEAULT, R. Occupation and the rebuilding of civil society: notes from the warzone. Journal of Occupational Science, Melbourne, v. 9, n. 1, p. 38-47, 2002. http:// dx.doi.org/10.1080/14427591.2002.9686492

THIBEAULT, R. Rebuilding lives and societies through occupation in post-conflict areas and highly marginalized settings. In: KRONENBERG, F.; POLLARD, N.; SAKELLARIOU, D. (Ed.). Occupational therapy without borders: towards an ecology of occupation-based practices. London: Elsevier Press, 2011. v. 2, p. 155-161.

TOWNSEND, E. A. Muriel Driver Memorial Lecture: Occupational therapy's social vision. Canadian Journal of Occupational Therapy, Thousand Oaks, v. 60, p. 174-184, 1993. http://dx.doi. org/10.1177/000841749306000403

TOWNSEND, E. A. Good intentions overruled: a critique of empowerment in the routine organization of mental health services. Toronto: University of Toronto Press, 1998a.

TOWNSEND, E. A. Reflections on... occupational therapy language: Matters of respect, accountability and leadership. Canadian Journal of Occupational Therapy, Thousand Oaks, v. 65, n. 1, p. 45-50, 1998b. http:// dx.doi.org/10.1177/000841749806500106

TOWNSEND, E. A. The 2010 Townsend and Polatajko Lecture in Occupational Science. Boundaries and bridges to adult mental health: Critical occupational and capabilities perspectives of justice. Journal of Occupational Science, Melbourne, v. 19, n. 1, p. 8-24, 2012.

TOWNSEND, E. A.; POLATAJKO, H. Enabling occupation II: advancing occupational therapy vision for health, well-being and justice through occupation. 2nd ed. Ottawa: CAOT Publications ACE, 2013.

TOWNSEND, E. A. et al. Introducing the leadership in enabling occupation (LEO) model. Canadian Journal of Occupational Therapy, Thousand Oaks, v. 78, 255-259, 2011. http://dx.doi.org/10.2182/ cjot.2011.78.4.7

TOWNSEND, E. A.; SANDIFORD, M. Reaching out: today's activist occupational therapy. Disponível em: <http://youtu.be/LIcfyQ3RwT0>. Acesso em: 08 fev. 2012. Short version: <http://youtu.be/_RXL4V505Bw>.

TOWNSEND, E. A. et al. Linking occupation and place in community health. Journal of Occupational Science, Melbourne, v. 16, n. 1, p. 50-55, 2009.

TOWNSEND, E. A.; WHITEFORD, G.; HOCKING, C. Reflections on... occupational therapy language: Matters of respect, accountability and leadership. Canadian Journal of Occupational Therapy, Thousand 
Oaks, California, v. 65, n. 1, p. 45-50, 1998. http:// dx.doi.org/10.1177/000841749806500106

TOWNSEND, E. A.; WILCOCK, A. A. Occupational justice and client-centered practice: a dialogue in progress. Canadian Journal of Occupational Therapy, Thousand Oaks, v. 71, n. 2, p. 75-87, 2004a. http://dx.doi. org/10.1177/000841740407100203

TOWNSEND, E. A.; WILCOCK, A. A. Occupational justice. In: CHRISTIANSEN, C.; TOWNSEND, E. A. Introduction to occupation. Thorofare: Prentice Hall, 2004b. p. 243-273.

VAN BRUGGEN, H. Eastern European transition countries: capability development for social reform. In: KRONENBERG, F.; POLLARD, N.; SAKELLARIOU, D. (Ed.). Occupational therapy without borders: towards an ecology of occupation-based practices. London: Elsevier Press, 2011. v. 2, p. 295-303.

WHITEFORD, G. Occupational deprivation and incarceration. Journal of Occupational Science, Melbourne, n. 3, p. 126-130, 1997. http://dx.doi.org/10.1080/1442 7591.1997.9686429

WHITEFORD, G. Autonomy, accountability, and professional practice: contemporary issues and challenges. New Zealand Journal of Occupational Therapy, Wellington, v. 54, n. 1, p. 11-14, 2007.

WHITEFORD, G.; TOWNSEND, E. A. A participatory occupational justice framework: enabling occupational participation and inclusion. In: KRONENBERG, F.; POLLARD, N.; SAKELLARIOU, D. (Ed.). Occupational therapy without borders: towards an ecology of occupationbased practices. London: Elsevier Press, 2011. v. 2, p. $65-84$

WHITEFORD, G.; TOWNSEND, E. A.; HOCKING, C. What is this occupational renaissance? Canadian Journal of Occupational Therapy, Thousand Oaks, v. 67, p. 59-67, 2000.

WHITEFORD, G.; WRIGHT-ST CLAIR, V. (Ed.). Occupation and practice in context. Marrickville: Elsevier Australia, 2005.

WILCOCK, A. A. A theory of the human need for occupation. Journal of Occupational Science, Melbourne, v. 1, n. 1, p. 17-24, 1993. http://dx.doi.org/10.1080/144 27591.1993 .9686375

WILCOCK, A. A. An occupational perspective of health. Thorofare: Slack Inc., 1998a.

WILCOCK, A. A. Reflections on doing, being, and becoming. Canadian Journal of Occupational Therapy, Thousand Oaks, v. 65, n. 5, p. 248-257, 1998b. http:// dx.doi.org/10.1177/000841749806500501

WILCOCK, A. A. Occupational Science: Bridging Occupation and Health. Canadian Journal of Occupational Therapy, Thousand Oaks, v. 72, p. 5-12, 2005a. http:// dx.doi.org/10.1177/000841740507200105

WILCOCK, A. A. Older people and occupational justice. In: McINTYRE, A.; ATWAL, A. (Eds.). Occupational therapy and older people. Oxford: Blackwell, 2005b. p. 14-26.

WILCOCK, A. A. Occupational justice approach. In: WILCOCK, A. An occupational perspective of health. 2nd ed. Thorofare: Slack, 2006. p. 244-270. http://dx.doi.org/10.1080/14427591.2000.9686470

WILCOCK, A. A.; TOWNSEND, E. A. Occupational justice: occupational terminology interactive dialogue. Journal of Occupational Science, Melbourne, v. 7, n. 2, p. 84-86, p. 244-270, 2000.

WILCOCK, W.; TOWNSEND, E. A. Occupational justice. In: SCHELL, B. et al. (Ed.). Willard and Spackman's Occupational Therapy. 12th ed. Philadelphia: Wolters Kluwer Health, Lippincott Williams \& Wilkins, 2014. p. 541-552. No prelo.

WILDING, C.; WHITEFORD, G. Language, identity and representation: occupation and occupational therapy in acute settings. Australian Occupational Therapy Journal, Melbourne, v. 54, p. 180-187, 2008.

WILSON, N. et al. Getting to social action: the youth empowerment strategies (YES!) project. Health Promotion Practice, Thousand Oaks, v. 9, n. 4, p. 395-403, 2008. http://dx.doi.org/10.1177/1524839906289072

WOLF, L. et al. Applying an occupational justice framework. Occupational Therapy Now, Ottawa, Canada, v. 1, p 15-18, 2010.

WORLD FEDERATION OF OCCUPATIONAL THERAPISTS - WFOT. Special Issue on Human Rights. Bulletin, v. 62, November, 2010.

WORLD FEDERATION OF OCCUPATIONAL THERAPISTS - WFOT. Position statement on human rights. [s.1.]: WFOT, 2006. Disponível em: <http://www. wfot.com/office_files/Human\%20Rights \%20Position $\% 20$ Statement\%20Final.pdf $>$. Acesso em: 1 mar. 2013.

WORLD FEDERATION OF OCCUPATIONAL THERAPISTS - WFOT. Minimum Standards for the Education of Occupational Therapists. [s.l.]: WFOT, 2002. Disponível em: <http:/www.wfot.org/ResourceCentre. aspx>. Acesso em: 1 mar. 2013.

WORLD HEALTH ORGANIZATION - WHO. Ottawa charter for health promotion: an international conference on health promotion Health Canada. Geneva: WHO, 1986. Disponível em: <http:/www.who.int/healthpromotion/ conferences/previous/ottawa/en/>. Acesso em: 1 mar. 2013. WORLD HEALTH ORGANIZATION - WHO. Health for all in the twenty-first century. Geneva: WHO, 1998. Document A51/5. Disponível em: <http://www.euro. who.int/_data/assets/pdf_file/0003/88590/EHFA5-E. pdf $>$. Acesso em: 1 mar. 2013.

YERXA, E. J. et al. Occupational science: the foundation for new models of practice. In: JOHNSON, J. A.; YERXA, E. J. (Ed.). Occupational science. New York: The Haworth Press, 1990. p. 1-17.

ZEMKE, R.; CLARK, F. Occupational Science: The evolving discipline. Philadelphia: F.A. Davis, 1996. 


\section{Author's Contributions}

Elizabeth Townsend and Rebecca Marval are responsible for the conception, writing and analyses.

\section{Notes}

${ }^{1}$ See also critiques of the medical diagnosis of bodily impairments as a potential source of social injustice.

${ }^{2}$ Discussions about occupational rights versus occupational justice are beyond this paper. See opening discussions on this point in Durocher, Gibson and Rappolt (2013), Hammell (2008) and Hammell and Iwama (2012).

${ }^{3}$ WFOT formed an International Advisory Group (WFOT - IAG) on Human Rights. The IAG sponsored a WFOT Bulletin Special Issue on Human Rights (WORLD..., November 2010, Edited by W. Bryant), held workshops from Asia to Australia and Europe, and has submitted recommendations to WFOT for incorporating human rights in the Minimum Standards for the Education of Occupational Therapists (WORLD..., 2002).

${ }^{4}$ YouTube access includes a 9.12 minute short version. http://youtu.be/_RXL4V505Bwand a 25.33-minute full version http://youtu.be/LIcfyQ3RwT0.Consent was obtained from the Dalhousie University Health Research Ethics Board \#2006-1433.

${ }^{5}$ Apologies are extended to those who have published important work that was omitted from Table 1. 